HETEROCYCLES, Vol. 104, No. 1, 2022, pp. 178 - 184. @ 2022 The Japan Institute of Heterocyclic Chemistry Received, 4th October, 2021, Accepted, 29th October, 2021, Published online, 4th November, 2021 DOI: $10.3987 / C O M-21-14565$

\title{
A NEW NATURAL BUTENOLIDE, (5R)-3-TETRADECYL-5-METHYL- 2(5H)-FURANONE, FROM OCTOCORAL CLADIELLA CONIFERA
}

\author{
Jhao-Syuan Zeng, ${ }^{\text {a, }{ }^{\dagger} \dagger}$ Shun-Hua Chen, ${ }^{\mathrm{c} \dagger}$ Yi-Hao Lo, ${ }^{\text {d,e,f }}$ Nan-Fu Chen, ${ }^{\text {g,h }}$ \\ Zhi-Hong Wen, ${ }^{\mathrm{e}, \mathrm{i}}$ Jih-Jung Chen, ${ }^{\mathrm{j}}$ Chia-Ching Liaw, ${ }^{*}$ and Ping-Jyun \\ Sung ${ }^{\mathrm{b}, \mathrm{e}, \mathrm{l}, \mathrm{m}, \mathbf{n} *}$
}

${ }^{a}$ Graduate Institute of Marine Biology, National Dong Hwa University, Pingtung 944401, Taiwan. ${ }^{\mathrm{b}}$ National Museum of Marine Biology and Aquarium, Pingtung 944401, Taiwan. ${ }^{c}$ Department of Nursing, Fooyin University, Kaohsiung 831301, Taiwan. ${ }^{\mathrm{d}}$ Department of Family Medicine, Zuoying Branch of Kaohsiung Armed Forces General Hospital, Kaohsiung 813204, Taiwan. ${ }^{\text {e }}$ Department of Marine Biotechnology and Resources, National Sun Yat-sen University, Kaohsiung 804201, Taiwan. ${ }^{\mathrm{f}}$ Institute of Medical Science and Technology, National Sun Yatsen University, Kaohsiung 804201, Taiwan. g Division of Neurosurgery, Department of Surgery, Kaohsiung Armed Forces General Hospital Kaohsiung 802301, Taiwan. ${ }^{\mathrm{h}}$ Center for General Education, Cheng Shiu University, Kaohsiung 833301, Taiwan. ${ }^{\text {i }}$ Institute of BioPharmaceutical Sciences, National Sun Yat-sen University, Kaohsiung 804201, Taiwan. ${ }^{j}$ Faculty of Pharmacy, School of Pharmaceutical Sciences, National Yang-Ming Chiao Tung University, Taipei 112304, Taiwan. ${ }^{k}$ Division of Chinese Materia Medica Development, National Research Institute of Chinese Medicine, Taipei 112304, Taiwan. ${ }^{1}$ Chinese Medicine Research and Development Center, China Medical University Hospital, Taichung 404394, Taiwan. ${ }^{m}$ Graduate Institute of Natural Products, Kaohsiung Medical University, Kaohsiung 807378, Taiwan. ${ }^{n}$ Ph.D. Program in Pharmaceutical Biotechnology, Fu Jen Catholic University, New Taipei 242062, Taiwan.

E-mail: liawcc@nricm.edu.tw,pjsung@nmmba.gov.tw

${ }^{\dagger}$ Equal contribution to this article.

Abstract - A chemical examination of Cladiella conifera, octocoral collected in the waters of Taiwan, resulted in isolation of a new natural butenolide, (5R)-3tetradecyl-5-methyl-2(5H)-furanone (1). The structure, including the absolute 
configuration, of $\mathbf{1}$ was established by spectroscopic analysis and $\mathbf{1}$ was found to inhibit the generation of COX-2 from RAW 264.7 stimulated by LPS.

Octocorals belonging to genus Cladiella were found to be rich sources of interesting natural products, of which many were proved to exhibit extensive biomedical proficiency through bioactivities. ${ }^{1}$ In our continuing studies of new natural substances from marine invertebrates distributed in Taiwanese reef systems locating in a highly biodiverse environment provided by convergence of the Kuroshio current and South China Sea surface current, an octocoral identified as Cladiella conifera (Tixier-Durivault, 1943) (phylum Cnidaria, class Anthozoa, subclass Octocorallia, order Alcyonacea, suborder Alcyoniina, family Alcyoniidae $)^{2}$ was collected off the Penghu Archipelago. Chemical examination of the EtOAc soluble fraction of this specimen resulted in the isolation of a new natural butenolide derivative (5R)-3-tetradecyl5-methyl-2(5H)-furanone (1) (Chart 1). Butenolide derivatives are occasionally encountered among various marine invertebrates, such as sponges, ${ }^{3,4}$ brittle stars,${ }^{5}$ octocorals, ${ }^{6-8}$ and marine microorganisms, including Gram-positive bacterium Streptomyces spp.,${ }^{9,10}$ fungus Aspergillus terreus,,${ }^{11,12}$ Paecilomyces variotii, ${ }^{13}$ and Paradendryphiella salina. ${ }^{14}$ These butenolides of marine origin were found to possess potential bioactivities in cytotoxicity, ${ }^{5}$ antifouling activity, ${ }^{8}$ PPAR $\alpha$ agonistic activity, ${ }^{9} \alpha$-glucosidase inhibitory activity, ${ }^{11,12}$ anti-inflammatory activity, ${ }^{12}$ antiradical activity, ${ }^{12,13}$ and antibacterial effects. ${ }^{12,14}$ As follows is the description of isolation, structural characterization, and bioactivity of butenolide $\mathbf{1}$.

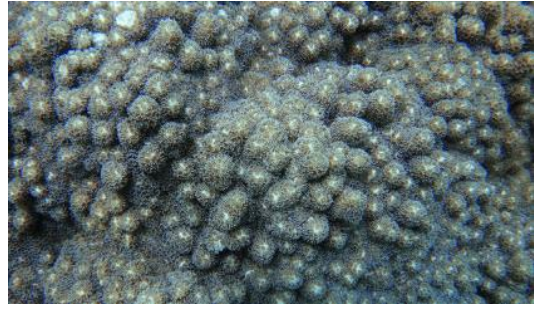

Cladiella conifera

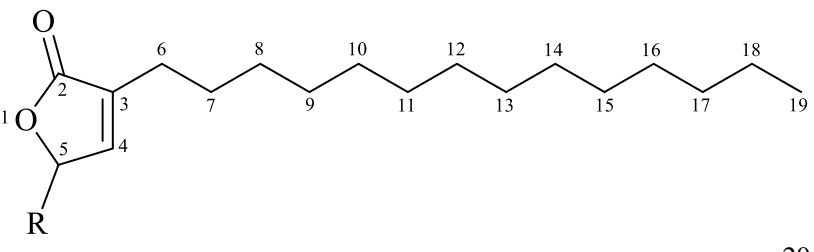

20

(5R)-3-tetradecyl-5-methyl-2(5H)-furanone $(\mathbf{1}): \mathrm{R}=\beta$-Me (5S)-3-tetradecyl-5-methyl-2(5H)-furanone (2): $\mathrm{R}=\alpha$-Me

Chart 1. A picture of Cladiella conifera and the structures of (5R)-3-tetradecyl-5-methyl-2(5H)-furanone (1) and (5S)-3-tetradecyl-5-methyl-2(5H)-furanone (2)

Compound 1 was obtained as an amorphous solid and had a molecular formula $\mathrm{C}_{19} \mathrm{H}_{34} \mathrm{O}_{2}$ from (+)HRESIMS at $m / z 317.24534[\mathrm{M}+\mathrm{Na}]^{+}\left(\mathrm{Calcd}\right.$ for $\left.\mathrm{C}_{19} \mathrm{H}_{34} \mathrm{O}_{2}+\mathrm{Na}, 317.24510\right)$ (unsaturation degrees $=3$ ) . The IR spectrum pointed out an absorption at $1743 \mathrm{~cm}^{-1}$, suggesting the presence of an $\alpha, \beta$-unsaturated $\gamma$ lactone carbonyl functional group. The ${ }^{13} \mathrm{C}$ NMR spectrum (Table 1), in combination with DEPT and HSQC spectra, revealed the presence of one $\gamma$-lactone moiety $\left(\delta_{\mathrm{C}} 173.9, \mathrm{C}-2\right)$ and one trisubstituted olefin $\left(\delta_{\mathrm{C}} 134.3, \mathrm{C}-3 ; 148.8, \mathrm{CH}-4\right)$. As one double bond and one carbonyl accounted for two of the three doublebond equivalents, 1 must be a monocyclic compound. Based on the ${ }^{13} \mathrm{C}$ NMR data and numbers of unsaturation, 1 established as a butenolide analogue. 
The ${ }^{1} \mathrm{H}$ NMR and HSQC spectra of 1 showed the presence of one olefinic proton signal at $\delta_{\mathrm{H}} 6.98(1 \mathrm{H}$, q, $J=1.2 \mathrm{~Hz})$, that was attributed to $\mathrm{H}-4$ of a butenolide. Additionally, a signal at $\delta_{\mathrm{H}} 4.99(1 \mathrm{H}, \mathrm{qq}, J=6.8$, $1.6 \mathrm{~Hz}$ ) was characteristic of the H-5 oxymethine resonance of a butenolide. In addition, a methyl doublet was observed at $\delta_{\mathrm{H}} 1.40\left(3 \mathrm{H}\right.$, br d, $\left.J=6.8 \mathrm{~Hz}, \mathrm{H}_{3}-20\right)$. The ${ }^{13} \mathrm{C}$ NMR resonances at $\delta_{\mathrm{C}} 173.9(\mathrm{C}-2), 134.3$ (C-3), $148.8(\mathrm{CH}-4), 77.4(\mathrm{CH}-5)$, and $19.2\left(\mathrm{CH}_{3}-20\right)$ were characteristic of the $\alpha, \beta$-unsaturated $\gamma$-methyl$\gamma$-lactone of a butenolide. Analysis of ${ }^{1} \mathrm{H}-{ }^{1} \mathrm{H}$ COSY spectrum provided two spin systems of protons $\mathrm{H}-4 / \mathrm{H}-$ 5/H3-20 and $\mathrm{H}_{2}-6$ to $\mathrm{H}_{3}-19$ (Figure 1). These two fragments were connected by the key HMBC correlations between protons and non-protonated carbons such as $\mathrm{H}-4 / \mathrm{C}-2$, C-3; H-5/C-3; $\mathrm{H}_{2}-6 / \mathrm{C}-2$, C-3; and $\mathrm{H}_{2}-7 / \mathrm{C}-$ 3 (Figure 1). Lastly, consideration of the remaining unsaturation degree determined the $\alpha, \beta$-unsaturated $\gamma$ lactone bearing a linear chain and a methyl at the $\alpha$ - and $\gamma$-positions, respectively.

Table 1. ${ }^{1} \mathrm{H}$ and ${ }^{13} \mathrm{C}$ NMR data for butenolide 1

\begin{tabular}{|c|c|c|}
\hline Position & $\delta_{\mathrm{H}}(J \text { in } \mathrm{Hz})^{\mathrm{a}}$ & $\delta_{\mathrm{C},}{ }^{\mathrm{b}} \mathrm{Mult}^{\mathrm{c}}$ \\
\hline 2 & & $173.9, \mathrm{C}$ \\
\hline 3 & & $134.3, \mathrm{C}$ \\
\hline 4 & $6.98 \mathrm{q}(1.2)$ & $148.8, \mathrm{CH}$ \\
\hline 5 & $4.99 \mathrm{qq}(6.8,1.6)$ & $77.4, \mathrm{CH}$ \\
\hline 6 & $2.26 \mathrm{tt}(7.6,1.6)$ & $25.2, \mathrm{CH}_{2}$ \\
\hline 7 & 1.54 quint (7.6) & $27.4, \mathrm{CH}_{2}$ \\
\hline \multirow[t]{9}{*}{$8-16$} & $1.25-1.34 \mathrm{~m}$ & $29.17, \mathrm{CH}_{2}$ \\
\hline & & $29.30, \mathrm{CH}_{2}$ \\
\hline & & $29.34, \mathrm{CH}_{2}$ \\
\hline & & $29.51, \mathrm{CH}_{2}$ \\
\hline & & $29.60, \mathrm{CH}_{2}$ \\
\hline & & $29.63, \mathrm{CH}_{2}$ \\
\hline & & $29.63, \mathrm{CH}_{2}$ \\
\hline & & $29.66, \mathrm{CH}_{2}$ \\
\hline & & 29.67, $\mathrm{CH}_{2}$ \\
\hline 17 & $1.25 \mathrm{~m}$ & $31.9, \mathrm{CH}_{2}$ \\
\hline 18 & $1.28 \mathrm{~m}$ & $22.7, \mathrm{CH}_{2}$ \\
\hline 19 & $0.88 \mathrm{t}(7.2)$ & $14.1, \mathrm{Me}$ \\
\hline 20 & $1.40 \mathrm{br} \mathrm{d}(6.8)$ & 19.2, Me \\
\hline
\end{tabular}

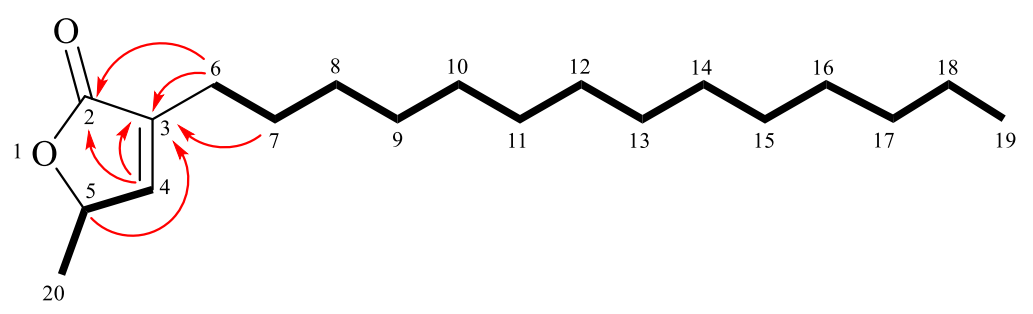

Figure 1. Key COSY $(-)$ and $\mathrm{HMBC}(\frown)$ correlations of $\mathbf{1}$

Gawronski et al. established a method for determining the absolute configuration of butenolides using CD (circular dichroism) spectra, such is when a butenolide has a negative Cotton effect $\left(\pi-\pi^{*}\right)$ between 200 and $220 \mathrm{~nm}$, the absolute configuration of C-5 is $R .^{15}$ The CD spectrum of butenolide 1 (Figure 2) provided a negative Cotton effect at $220 \mathrm{~nm}$, and the absolute configuration at C-5 of $\mathbf{1}$ was assigned as $R$ accordingly. 
Furthermore, it was found that the planar structure of $\mathbf{1}$ was identical to that of known synthetic butenolides, (5R)-3-tetradecyl-5-methyl-2( $5 H)$-furanone and its enantiomer $(5 S)$-3-tetradecyl-5-methyl-2 $(5 H)$-furanone (2) (Chart 1). ${ }^{16}$ By comparison of the rotation value of $\mathbf{1}\left([\alpha]_{\mathrm{D}}^{25}-23\left(c 1.33, \mathrm{CHCl}_{3}\right)\right)$ with that of $(5 R)-3$ tetradecyl-5-methyl-2(5H)-furanone $\left([\alpha]_{\mathrm{D}}^{20}-20.1\left(c \text { 2.06, } \mathrm{CH}_{2} \mathrm{Cl}_{2}\right)\right)^{16}$ and $(5 S)$-3-tetradecyl-5-methyl2(5H)-furanone $\left([\alpha]_{\mathrm{D}}^{20}+27.2\left(c 2.02, \mathrm{CH}_{2} \mathrm{Cl}_{2}\right) ;{ }^{16}[\alpha]_{\mathrm{D}}^{23}+27.7\left(c 2.3, \mathrm{CH}_{2} \mathrm{Cl}_{2}\right)^{17}\right)$, the absolute configuration for C-5 stereogenic center of $\mathbf{1}$ was further confirmed as $R$ form. Therefore, the structure of $\mathbf{1}$ was determined unequivocally based on the above findings. Butenolide 1 was isolated from a natural source unprecedentedly and so was butenolide analogues obtained from octocorals belonging to genus Cladiella.

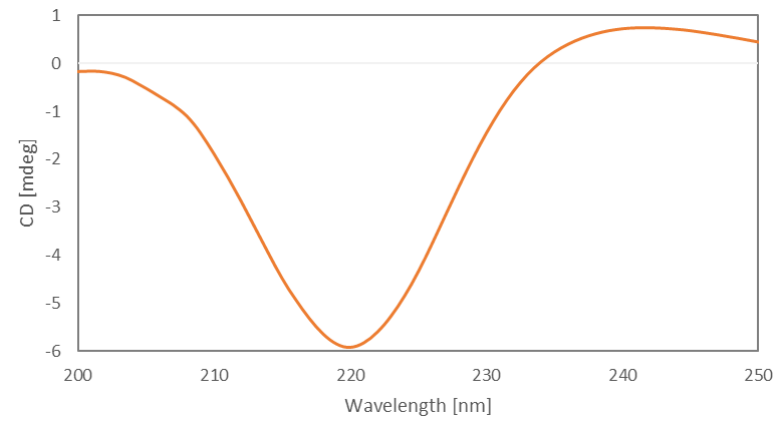

$220 \mathrm{~nm}(\Delta \varepsilon=-5.8, c 3.33 \mathrm{ppm}, \mathrm{MeOH})$

Figure 2. CD spectrum of 1

According to Klapper et al. study, ${ }^{18}$ the generation of butenolide $\mathbf{1}$ is suggested that starts from a 3-oxo thioester fatty acid derivative $\mathbf{2}$ with glyceraldehyde-3-phosphate to yield $\mathbf{3}$ via Knoevenagel condensation. Subsequently, $\mathbf{3}$ is reduced to alcohol $\mathbf{4}$ by a short-chain reductase. Further, an oxidoreductase reacts with 4 to produce an exo-methylene moiety to obtain $\mathbf{5}$, and a reduction occurs to yield $\mathbf{6}$. Finally, the hydroxy group in $\mathbf{6}$ is removed by deoxidation to generate butenolide $\mathbf{1}$.

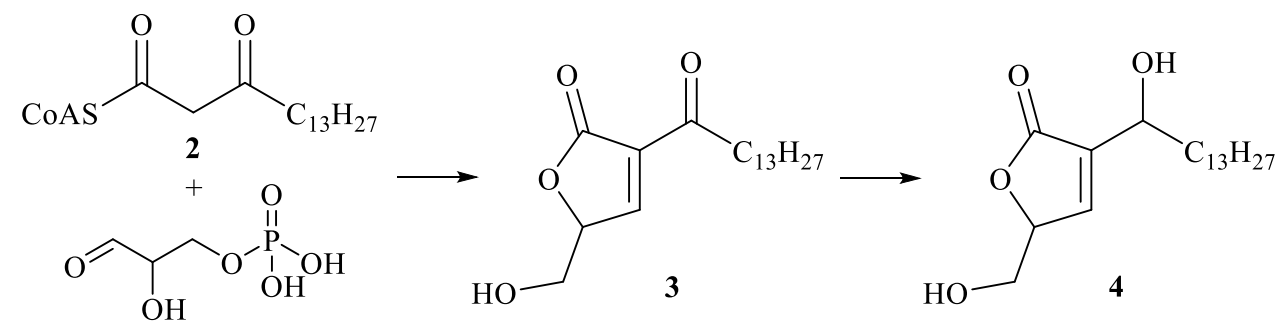

glyceraldehyde-3-phosphate

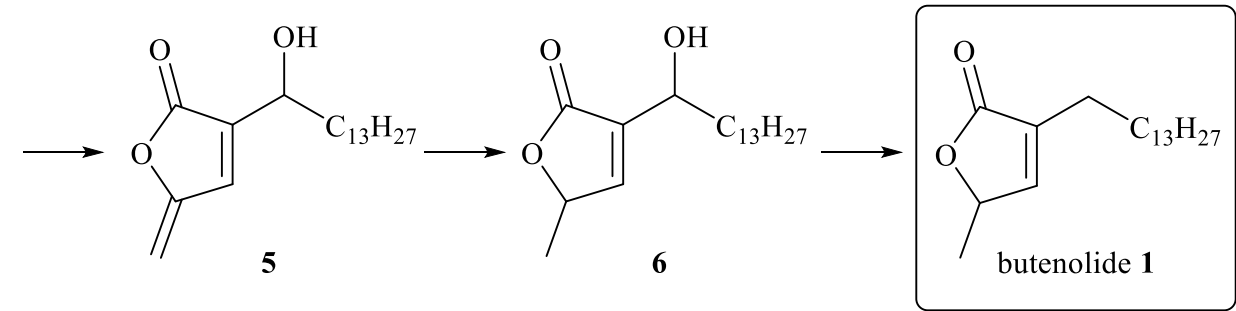

Figure 3. The plausible biosynthetic pathway of $\mathbf{1}$ 
The effect of butenolide 1 on the release of cyclooxygenase-2 (COX-2) from lipopolysaccharide(LPS)stimulated RAW264.7 macrophage cells was assessed. Butenolide 1 at $10 \mu \mathrm{M}$ suppressed the release of COX-2 to $84.5 \pm 2.8 \%$, as compared to the results of the cells stimulated with LPS only.

\section{EXPERIMENTAL}

General Experimental Procedures. Optical rotations were measured using a JASCO P-1010 digital polarimeter. IR spectra were measured on a Thermo Scientific Nicolet iS5 FT-IR spectrophotometer. CD spectrum was recorded on a JASCO J-815 circular dichroism (CD) spectropolarimeter in MeOH. NMR spectra were taken on a $400 \mathrm{MHz}$ Jeol NMR (model ECZ $400 \mathrm{~S}$ ) spectrometer operating at $400 \mathrm{MHz}$ for ${ }^{1} \mathrm{H}$ and $100 \mathrm{MHz}$ for ${ }^{13} \mathrm{C}$ in $\mathrm{CDCl}_{3}$ using the residual $\mathrm{CHCl}_{3}$ signal $\left(\delta_{\mathrm{H}} 7.26 \mathrm{ppm}\right)$ and $\mathrm{CDCl}_{3}\left(\delta_{\mathrm{C}} 77.1 \mathrm{ppm}\right)$ as the internal standards for ${ }^{1} \mathrm{H}$ and ${ }^{13} \mathrm{C}$ NMR, respectively; coupling constants $(J)$ are given in Hz. ESIMS and HRESIMS were recorded using a Bruker APEX II FTMS system. Column chromatography was carried out with silica gel (230-400 mesh, Merck). TLC was performed on plates precoated with DC-Fertigfolien Alugram $^{\circledR}$ Xtra SIL G/UV 254 (0.20-mm-thick, Macherey-Nagel) and RP-18W/UV 254 (0.15-mm-thick, Macherey-Nagel), then sprayed with $10 \% \mathrm{H}_{2} \mathrm{SO}_{4}$ solution followed by heating to visualize the spots. Normal-phase HPLC (NP-HPLC) was performed using a system comprised of a Hitachi L-7100 pump, a Rheodyne 7725i injection port, and a normal-phase column (YMC-Pack SIL, $250 \times 20 \mathrm{~mm}, 5 \mu \mathrm{m}$; SigmaAldrich). Reverse-phase HPLC (RP-HPLC) was performed using a system comprised of a Hitachi L-2130 pump, a Hitachi L-2455 photodiode array detector, and a Rheodyne 7725i injection port. A reverse-phase column (Luna, $5 \mu \mathrm{m}, \mathrm{C} 18(2) 100 \AA, 250 \times 21.2 \mathrm{~mm}$ ) was used for RP-HPLC.

Animal Materials. Specimens of $C$. conifera were collected in May 2017 by hand with SCUBA divers off the coast of Penghu Archipelago, Taiwan (N23.15.203, E119.30.725). A voucher specimen was deposited in the National Museum of Marine Biology \& Aquarium, Taiwan (NMMBA-TW-SC-2017-0504).

Extraction and Isolation. $C$. conifera (wet/dry weight $=171 / 59 \mathrm{~g}$ ) were sliced and then extracted with a solvent mixture of $\mathrm{MeOH}$ and $\mathrm{CH}_{2} \mathrm{Cl}_{2}$ (1:1). The extract was partitioned between EtOAc and $\mathrm{H}_{2} \mathrm{O}$. The EtOAc layer (3.86 g) was then applied on silica gel column and eluted with gradients of $n$-hexane/EtOAc (from $n$-hexane to $100 \%$ EtOAc) to furnish 12 sub-fractions. Among them, fraction 5 was separated by NPHPLC, using a solvent mixture of $n$-hexane/EtOAc (19:1) to yield 8 sub-fractions 5A-5H. Fraction 5C was further purified by RP-HPLC, using an isocratic solvent system of $\mathrm{MeOH} / \mathrm{H}_{2} \mathrm{O}$ mixture (87:13; flow rate = $5 \mathrm{~mL} / \mathrm{min})$ to afford $\mathbf{1}(5.1 \mathrm{mg})$.

(5R)-3-Tetradecyl-5-methyl-2(5H)-furanone (1): amorphous powder; $[\alpha]_{\mathrm{D}}^{25}-23\left(c\right.$ 1.33, $\left.\mathrm{CHCl}_{3}\right)\left(\right.$ ref. $^{16}$ $\left.[\alpha]_{\mathrm{D}}^{20}-20.1\left(c 2.06, \mathrm{CH}_{2} \mathrm{Cl}_{2}\right)\right)$; IR $v_{\max } 1743 \mathrm{~cm}^{-1} ;{ }^{1} \mathrm{H}\left(\mathrm{CDCl}_{3}, 400 \mathrm{MHz}\right)$ and ${ }^{13} \mathrm{C}\left(\mathrm{CDCl}_{3}, 100 \mathrm{MHz}\right) \mathrm{NMR}$ 
data, see Table 1; ESIMS m/z $317[\mathrm{M}+\mathrm{Na}]^{+}$; HRESIMS $m / z 317.24534\left(\right.$ Calcd for $\mathrm{C}_{19} \mathrm{H}_{34} \mathrm{O}_{2}+\mathrm{Na}$, 317.24510).

In Vitro Anti-inflammatory Assay. The inflammatory assay was employed to evaluate the activity of butenolide 1 related to the release of COX-2 from macrophage cells as the literature reported. ${ }^{19,20}$

\section{ACKNOWLEDGEMENTS}

The authors are grateful to Ms. Chao-Lien Ho and Hsiao-Ching Yu at the High Valued Instrument Center, National Sun Yat-sen University, for providing the NMR (NMR001100) and mass (MS000600) spectra (MOST 110-2731-M-110-001). This work was mainly funded by grants from the National Museum of Marine Biology and Aquarium, the National Dong Hwa University, the Fooyin University, and the Ministry of Science and Technology (MOST 110-2314-B-242-003, 109-2320-B-291-001-MY3, and 107-2320-B291-001-MY3), Taiwan, awarded to Shun-Hua Chen and Ping-Jyun Sung. All funding is gratefully acknowledged.

\section{REFERENCES}

1. P. Radhika, Biochem. Syst. Ecol., 2006, 34, 781.

2. Y. Benayahu, L. P. van Ofwegen, C.-F. Dai, M.-S. Jeng, K. Soong, A. Shlagman, S. W. Du, P. Hong, N. H. Imam, A. Chung, T. Wu, and C. S. McFadden, Zool. Stud., 2018, 57, 50.

3. V. K. Phan, X. N. Nguyen, V. Q. Ngo, V. M. Chau, H. N. Nguyen, T. C. Nguyen, L. T. A. Hoang, H. T. Bui, H. Y. Pham, X. C. Nguyen, P. T. Nguyen, T. H. Nguyen, N. Y. Kim, S. J. Park, and S. H. Kim, Nat. Prod. Commun., 2013, 8, 1751.

4. S. Khushi, L. Nahar, A. A. Salim, and R. J. Capon, Mar. Drugs, 2018, 16, 456.

5. J. Lee, W. Wang, J. Hong, C.-O. Lee, S. Shin, W. S. Im, and J. H. Jung, Chem. Pharm. Bull., 2007, 55, 459.

6. H. Kikuchi, Y. Tsukitani, H. Nakanishi, I. Shimizu, S. Saitoh, K. Iguchi, and Y. Yamada, Chem. Pharm. Bull., 1983, 31, 1172.

7. A. D. Rodríguez and C. Ramírez, J. Nat. Prod., 1994, 57, 339.

8. H. Shi, S. Yu, D. Liu, L. van Ofwegen, P. Proksch, and W. Lin, Mar. Drugs, 2012, 10, 1331.

9. Y. Igarashi, M. Ikeda, S. Miyanaga, H. Kasai, Y. Shizuri, and N. Matsuura, J. Antibiot., 2015, $68,345$.

10. J. A. Monteiro de Oliveira, D. E. Williams, R. J. Andersen, M. H. Sarragiotto, and D. C. Baldoqui, Nat. Prod. Res., 2020, 34, 2986.

11. Z. Cheng, Y. Li, W. Liu, L. Liu, J. Liu, W. Yuan, Z. Luo, W. Xu, and Q. Li, Mar. Drugs, 2019, 17, 332.

12. J. Bao, X.-X. Li, F. He, X. Zhang, K. Zhu, H. Tao, J.-H. Yu, H. Liu, and H. Zhang, Tetrahedron Lett., 2020, 61, 152193. 
13. P. Zhang, X.-M. Li, J.-N. Wang, X. Li, and B.-G. Wang, Phytochem. Lett., 2015, 11, 85.

14. M. Vallet, Y.-M. Chong, A. Tourneroche, G. Genta-Jouve, C. Hubas, R. Lami, C. M. M. Gachon, T. Klochkova, K.-G. Chan, and S. Prado, Front. Mar. Sci., 2020, 7, 601.

15. J. K. Gawronski, A. van Oeveren, H. van der Deen, C. W. Leung, and B. L. Feringa, J. Org. Chem., 1996, 61, 1513.

16. B.-B. Zeng, T.-S. Hu, W. Yun, Y. Wu, and Y.-L. Wu, Enantiomer, 2002, 7, 133.

17. R. M. Ortuño, J. Bigorra, and J. Font, Tetrahedron, 1988, 44, 5139.

18. M. Klapper, K. Schlabach, A. Paschold, S. Zhang, S. Chowdhury, K.-D. Menzel, M. A. Rosenbaum, and P. Stallforth, Angew. Chem. Int. Ed., 2020, 59, 5607.

19. Y.-H. Jean, W.-F. Chen, C.-S. Sung, C.-Y. Duh, S.-Y. Huang, C.-S. Lin, M.-H. Tai, S.-F. Tzeng, and Z.-H. Wen, Br. J. Pharmacol., 2009, 158, 713.

20. L.-C. Chen, Y.-Y. Lin, Y.-H. Jean, Y. Lu, W.-F. Chen, S.-N. Yang, H.-M. D. Wang, I.-Y. Jang, I.-M. Chen, J.-H. Su, P.-J. Sung, J.-H. Sheu, and Z.-H. Wen, Molecules, 2014, 19, 14667. 